\title{
A Critical Review on Artavavaha Srotas as Concept of Female Reproductive System in Ayurveda
}

\author{
Lahange Sandeep Madhukar*1 and Bhangare Archana Nivrutti ${ }^{2}$ \\ ${ }^{1}$ Assistant Professor, Department of P.G Sharir Rachana NIA, India \\ ${ }^{2}$ Assistant Professor, Department of Kayachikitsa, P. G. Ayurvedic College and Hospital Mandi Govindgarh, India
}

Received: December 21, 2017; Published: January 18, 2018

*Corresponding author: Lahange Sandeep Madhukar Assistant Professor P. G. Department of Sharir Rachana NIA, Jaipur 302002, India, Email: sandiplahange@gmail.com

\begin{abstract}
According to Ayurveda, health of a female starts in the fetal stage itself which describes the measures to yield a good female child. The distinctive anatomical and physiological features of women in each age group were well studied by the ancient sages of Ayurveda. Just as the river is cleansed by its flow the women are purified by the menstrual flow. That is the reason for the non-susceptibility of women to many diseases. The regimens to be followed during menstrual and post-menstrual periods are well advocated in Ayurveda. Disregard to these regimens is the leading cause for many of the gynecological and systemic diseases in women. In addition to the systemic diseases, 20 gynecological diseases are described, which are explained in the classics under the entity of Yonivyapad and all the Yoni Roga are the disease of anatomical components of Artavavaha Srotas (Reproductive system).

In Ayurveda there is vast description of Artavavaha Srotas in terms of its moolsthana, Patho-physiology, clinical conditions and their ayurvedic management. Artavavaha Srotas shows quite similarities with female reproductive system explained in modern medical science. Anatomical defects of the reproductive system could be one of the commonest causes of bad obstetric history. Approximately 12 - $15 \%$ of women with recurrent abortion have uterine malformation. So there is need of time to elaborate the physio- anatomical and applied ayurvedic knowledge regarding female reproductive system for better female health.
\end{abstract}

Keywords: Ayurveda; Artavavaha Srotas; Female Reproductive System; Yonivyapad; Moolsthan

Abbreviations: ART: Assisted Reproductive Technology; HSG: Hystero Salpingo Grams; MRI: Magnetic Resonance Imaging

\section{Introduction}

Ayurveda explained different structures or parts of the Artavavaha Srotas which are similar to the structures of the female reproductive system. The term Bhaga is in Ayurveda refers to the Smaramandira and Yoni which shows similarity with Vulva. It is of 12 Angular in length. It seems to be the description of circumference of entire vulva instead of introitus of vagina. Thus the word Bhaga gives the meaning of Yoni, which denotes the external genital organs of female i.e. vulva or the introitus of vagina. Smaratpatra is situated in upper portion of the vagina similar to the clitoris which is highly stimulated/erectile structure during sexual act. The word Yoni in Ayurvedic classics refers to entire reproductive system and also as individual organs. The word Yoni is used in different contexts to denote different organs of female reproductive system [1-10].

The structure of the Yoni is like a conch shell, it is broader at start, kinked at middle and again broader at end. It is described to be composed of three Avarta. Prathamavarta comprises vagina and accompanying structures, Dwitiyavarta comprises cervix and accompanying structures and Tritiyavarta includes uterus along with its appendages. Garbhashaya consists of two words Garbha+Ashaya means the organ that holds the Garbha (the foetus) called Garbhashaya. It is placed between Pittashaya (small intestine) and Pakvashaya (large intestine). Yoni looks like a conch shell and it is composed of three Avarta and Garbhashaya is situated in the third Avarta of Yoni. Garbhashaya means uterine cavity which resemble to shape of fish named Rohit.

It is triangular in shape, apex being at the mouth, says that its mouth is small and mean while internal cavity is a big. Rajovahi Sira (uterine vessels) is the blood supply of the organ. While considering the concept of Artavavaha Srotas it can be understood by its functions, Moolsthan or retrogression method which means symptoms produced due to injury (Viddha Lakshana), or Dushti Lakshana (pathological changes) occurs in Artavavaha Srotas. Aratvavaha Srotas is physio-anatomical structure present in female pelvic cavity having Garbhashaya and Artavavahi Dhamani of its Moolsthan i.e., most important parts. It is quite related with female reproductive system of modern science in which uterus 
along with fallopian tube and ovary are the most important parts for its structural and functional essentiality. Concept of Artavavaha Srotas has been resolute in two ways Macroscopic and microscopic. Macroscopically it is considered as reproductive tract where menstruation, conception, and foetal development take place. While microscopically we must understand physiological aspect as Artavavaha Srotas is physio-anatomical concept [11-15].

Functions of reproductive system like ovulation, menstruation, conception, endometrial changes etc. all these are controlled by various hormones under HPO Axis while some functions happen due to its proper blood supply and nerve supply. Capillary network present in reproductive system also play significant role in nutrition, development and proper functioning of the whole system. Both Ayurveda and modern science accept that Fertilization, Implantation, nutrition and development of foetus take place in Garbhashaya (uterus). Any injury to the Artavavaha Srotas or its Moolsthan causes symptoms like menstrual disturbances, dyspareunia or even infertility which is also accepted and well explained by modern science. By all the above argument concerning Artavavaha Srotas shows reasonably similarities with reproductive system.

\section{Moolsthan of Artavavaha Srotas}

While considering the Moolsthan of any Srotas, following points are taken in consideration like Utpattisthan (origin point of view), Sangrahasthan (storage) and Vahanasthan (conduction). The Moolsthan or source is considered that without which the origin, maintenance and destruction of that specific carrier of body nutrient cannot be possible and the place which controls the entire functional dealings and processes of the specific carrier. In females, additional Srotas is explained named as Artavavaha Srotas. Ayurveda mentions the Garbhasaya and Artavavahi Dhamani as a Moolsthan of Artavavaha Srotas. Garbhashaya is mainly responsible for conception, production and expulsion Artava, from origin point of view. It shows same structural and functional characteristics of uterus along with ovaries and both have same pathological and clinical conditions after injury. Artavavahi Dhamani can be taken as fallopian tube which conducts Artava (ovum) towards uterus during menstrual phase and ovarian and uterine vessels, Dhamana word refers to contraction, hence in this study as by contracting fallopian tube conduct the ovum so it works like an Artavavahi Dhamani [16-25].

In Garbhashaya, the word Ashaya refers as cavity or space in that particular organ which are prime functional areas or cavities of the body. Garbhashaya is a space which helps in implantation and development of Garbha (foetus) here it doesn't refers to only a single organ but it is the hollow space in the body where various bio physiological activities happens. Yoni is a very important structure of female body, shaped as "Shankha Nabhi Akriti", contains three Avarta (circular folds) in its structure. Garbhashaya or Garbhashayya is an important structure situated in third Avarta of Yoni. Here the term Yoni has ample meaning represent the whole reproductive system of female in which shows three circular folds or subdivision yoni(vagina), Garbhashayamukha (cervical canal) and Garbhashayya (uterus) from external to internal respectively (Table 1).

Table 1: Shows the structure mentioned in Ayurveda having similarity with the organs of female reproductive system.

\begin{tabular}{|c|c|c|}
\hline Sr. No. & $\begin{array}{c}\text { Name of the organ of } \\
\text { Artavavaha Srotas }\end{array}$ & $\begin{array}{c}\text { Similar Organ In Female } \\
\text { Reproductive System }\end{array}$ \\
\hline 1 & Bhaga & Vulva or introitus \\
\hline 2 & Smaratpatra & Clitoris \\
\hline 3 & Yoni & Whole Reproductive system \\
\hline 4 & Garbhashaya & Uterus \\
\hline 5 & Antarphala & Ovary \\
\hline
\end{tabular}

There are number of important things to remember about "anatomical problems" that cause abnormality of menstrual disorders. First, uterine cancer accounts for less than 1\% of these. Although cancer is among the causes of menstrual disorders, it is rare in women under the age of 50 and, if caught early, is a very curable disease. Though, majority of women in their 30's and 40's who have periods that are heavy because of anatomic reasons, do not have cancer. For most women it is at least comforting to know that however inconvenient or disabling their symptoms may be, it is the rare woman with heavy periods that has uterine cancer. The uterus contains two types of tissue one is inner lining (endometrium) that sheds each month with menstrual cycle another muscular portion (myometrium). Both of these tissue types can develop growths. When the lining tissue develops growth, it called polyps. When the overgrowth of muscle tissue causes tumors, they are referred to as myomas (or fibroids) [26-34].

Fibroids mostly produce two types of symptoms like abnormal uterine bleeding and infertility (although other symptoms occur less frequently). Many women with fibroids don't have symptoms and the majority of them can simply choose to live with these benign tumors. Fibroids, as you can see from the drawing, can grow anywhere in the uterus. If a fibroid is closer to the center of the uterus (the inner cavity) it is more troublesome causing heavy menstrual bleeding and infertility (or miscarriages). Ayurveda is an open to discussion science. At every place, wherever it was concerned, Ayurvedic Seers have given the freedom to the thinkers and researchers to open a new window for the elaboration of the science. Because this work was based upon the literary review so it was a mere effort to understand Ayurvedic literature and its different prospective with relation to the modern day available sciences. This work is important in sense of exploration of Ayurveda within scientific background. Gynecology is a matter of concern for all of the medicinal sciences because- start of life begins with a baby only and health of the mother is the most important factor in this process. Today in totality, problems of gynecology are increasing day by day and Ayurveda has lot to contribute in this process. All the Ayurvedic Samhita have emphasized on this topic and this is the reason, why in each and every Samhita one can found some elaborated material about the gynecological problems.

In the same context all the Samhita and scholars of Ayurveda have a unified thought that Aartava represents the main and 
important activities of the females. This is a cyclic activity which can be understood in different ways. This activity not only represents the cyclic monthly blood flow from the vagina on gross level but also represents the hormonal changes related with the female reproductive system. Aartava makes women very specialized in sense of physiological activities. This physiological specialization is not possible without specialized anatomical structures. Clinical importance of the Aartava is very clear because in case of any female reproductive system related examination and questioning first question with everyone will be the pattern of the monthly menstrual flow. Srotas represents the "physiological entities" of the body on the gross level as well as on the subtle level both. Generally scholars have described the Srotas as some part of a particular system. The main concept of the Srotas seems very much clear after the review of the literature deeply- this is a concept of Physiological Anatomy and Pathological Anatomy.

As Ayurveda is a completely practical science and all the concepts described in Ayurveda are all about either for the maintenance of the health of a healthy individual or these are related with the cure of some diseases. In the same both physiology and pathology are most important to understand for any medical science. Medicinal sciences or health sciences can only be applied in every sense; these cannot be plain theoretical in any way. This is the reason perhaps nowadays modern medical sciences are also returning to the Ayurvedic way of understanding the Anatomy and are emphasizing on the functional anatomy more than the plain theoretical anatomy. Description of Srotas is mainly with the sense of functional anatomy suggests that a Srotas can represent the whole of the system easily. When it comes to defining the pair nature of the female genital system- this is made up of two parts- embryological view clears this. Second is the confusion over the number and counting of the Srotas. When text was seen properly, it is very clear that approach of Sushruta and Charaka Samhitas are entirely different, one thinks like a physician and other one's view is totally surgical.

Aartava and Srotas collaboratively are Aartava Vaha Srotas as stated above that this represents the whole female reproductive system, because all normal activities are quite impossible if one of these parts won't work properly. All minor and major parts of the system maintain its normal activities. These are the anatomical specifications of a part which decide the role and activity of that particular part and same is applicable on the Aartva Vaha Srotas or female reproductive system. Right from the positioning of a system up to the mucosal lining and blood and nervous supply, all parts together decides the activities of any system. There are different types of the anatomical anomalies in the female reproductive system. These can be classified into three parts on a whole-

a) Structural Deformities

b) Embryological Deformities

c) Histological Deformities

a) Structural Deformities: The structural deformities there is deformities like- Antramukhi, Phallini, Mahayoni, Vatiki Yoni, Prasransini along with Udvrtta and Apavrtta phala Yoni Vyapada.
These all structural deformities mainly represent the "dislocation", "displacement" and "disarrangement" of the female genital organs. Today modern medical sciences also agree that when there is some problem with the positioning of the uterus it may hamper the feminine characters and activities, very easily!

b) Embryological deformity: Under this heading we can summarize- Suchi Mukhi, Shandi and Bandhya Yoni Vyapadas. Beside this Kashypa has elaborated this very clearly and has given some other correlations by giving some examples of the different type of the vaginal openings on the basis of embryological developments. So all this can be used for the exploration of the embryological development and different anomalies,

c) Histological deformities: According to Ayurveda in this category Karnini and Yoni Kanda can be included because in these two deformities will be on histological levels.

There is no direct correlation possible in different conditions between Ayurveda with modern sciences because the way to acquire knowledge is totally different in both the sciences. Still there are some of the analogues based on the description available in the text. The table below is for the same "analogue" in different conditions of Ayurveda and Modern Science

\section{Discussion}

When we look at the Female genital system, this whole system is developed by two mullerian ducts during the development. These two fuse together and develops a complete system and this system as whole is one and same! This defies the "Copulate" nature of the Aartava Vaha Srotas as a whole and is perfect even in terms of the analogue of different thoughts from Ayurveda and Modern Anatomical Sciences. Secondly, any system works properly, when all of its components are working well, even small tiny cells are important in well functioning of the system. When we are looking at the human body, our approach should be subjective not objective. Anatomy in the text is not discussed to find out what and where alone in Ayurveda. The main purpose of the Anatomy in Ayurveda is to understand the structural importance to treat a patient and this should be taken in the same way. If the whole female genital system is Aartava Vaha Srotas then what is the Ayurvedic concept about that? This was the next quest in clearing the questions. There is an ample description of the Yoni and Garbhashya in the text, which clearly covers the whole genital system of the females.

According to Sushruta Samhita there are four "whorls" of the Yoni and these are situated in shape similar to a conch shell and every whorl represents a part of the female genital system. Coming to the anatomical deformities Women's health is a topic of concern in the medical field, as women are an important factor in the reproduction of healthy progeny. The environmental factors, fast-changing lifestyles, and various addictions (drug abuse) as well as excess use of drugs (like steroids) have endangered their health. Congenital or acquired anatomic defects remain important considerations in the investigation of recurrent pregnancy loss. When repeated first or second trimester losses, preterm delivery, or abnormal fetal presentations are documented, the suspicion 
of a structural abnormality should be high. Multitudes of female anatomical deformities are uncommon. However, their impact on reproduction can be profound. The aim of this review is to remind the practicing physician of the clinically relevant embryology and summarize the studies that look at the impact of such various anomalies on a woman's fecundity.

This retrospective longitudinal study was undertaken in order to determine the incidence and reproductive impact of uterine malformations on women desiring to conceive during their reproductive years. More couples where the female partner has a uterine anomaly are seeking care in the current clinical practice of reproductive medicine. This apparent increase is not due to a change in the prevalence of uterine anomalies in the population but is due the availability of better imaging techniques of the uterus itself and the practice of assisted reproductive technology (ART). In this era of ART, there has been more attention paid to the impact of Mullerian anomalies and their potential therapies on the outcomes of these assisted pregnancies.

The true prevalence of uterine anomalies in the population is unknown. It is insufficient to consult the older medical literature because of inconsistent diagnostic techniques utilized in the past and the heterogeneity of the subject populations that were studied. With the general wide spread use of transvaginal ultrasound and hysterosalpingograms (HSG) in reproductive-age women, increased detection of uterine anomalies in the general population can be expected, especially in the infertile and recurrent miscarriage subgroups. Following detection of uterine anomalies by ultrasound and HSG, the availability of magnetic resonance imaging (MRI) and three-dimensional ultrasound (3D US) should increase the accurate diagnosis of these anomalies as diagnostic criteria are applied more consistently. In 1998, the American Society for Reproductive Medicine (international organization of fertility experts) classified mullerian anomalies in an attempt to provide clinicians with a tool to better document the actual anomaly and subsequently follow their patients in regards to both conception and pregnancy outcome. In general, uterine anomalies present some difficulty in pregnancy retention and overall pregnancy outcome with natural conception and ART. Arcuate uterus probably has no impact on reproductive capacity.

The uterine septum is more definitively associated with recurrent miscarriage and, unlike the bicornuate uterus; surgical correction is technically easier and less morb the bicornuate uterus appears to suffer from an increased miscarriage rate and preterm delivery and the surgical repair is more extensive. The didelphic uterus was originally thought to have no impact on reproductive outcome. Re-evaluation of the literature shows that it does increase preterm deliveries and miscarriage rates. Like the unicornuate uterus, the didelphic uterus has an increased risk of malpresentation and cesarean section for dystocia. Patients with a unicornuate uterus have the poorest outcome: higher miscarriage rates, higher ectopic rates, higher preterm delivery rates and lower live-birth rates. In Ayurvedic classics majority of the gynecological disorders have been described under the heading of Yoni-vyapad. Some people perceive Yoni as vagina, but that is just the literal meaning. The real meaning comprises the whole female reproductive system. All the Yoni Roga is the disease of anatomic components of reproductive organs like vagina, cervix, and uterus. No work is complete in terms of studies and research. This work needs more exploration with help of some clinical surveys and studies so that we can elaborate the clinical anatomy in Ayurveda. Clinical contribution is more important for any health science and Ayurvedic Anatomy has a wide space for that.

\section{Conclusion}

A. Artavavaha Srotas shows quite similarity with the female reproductive system of modern medical science. It is determined in two ways macroscopic and microscopic. Macroscopically it is reproductive tract as conducting point of view and microscopically it is capillary network of uterus in context of nutrition point of view.

B. Moolsthan of Artavavaha Srotos are the regions or structures in the body from where Artava originates, store for small duration and carry for ejection outside body. Here Garbhashaya (uterus) and Artavavahi Dhamani (blood vessels and capillaries of uterus) are the Moolsthan of Artavavaha Srotas.

C. The clinical conditions related to Rituchakra (Menstrual cycle) are resulting from a range of factors such as hormone levels, anatomical deformities, functioning of the central nervous system, health of the reproductive organs.

D. Finally we conclude that, the Concept of female reproductive system is well explained in Ayurveda in terms of Artavavaha Srotas along with its basic units, physio-anatomy, clinical conditions and their Ayurvedic management in proper manor.

\section{References}

1. Brahma Shankar Shastri (1969) Bhava Mishra, Bhavprakash Samhita Vidyotini Commentary by Chaukhamba Sanskrit Series ( $5^{\text {th }}$ edn.) Varanasi, India.

2. Murthy K R Srikanth (1998) Bhava Mishra, Bhavprakash Samhita English Translation by Krishnadas Academy ( $1^{\text {st }}$ edn.) Vanarasi, India.

3. K H Krishnamurthy Bhela (2000) Bhela Samhita by Chaumkhambha Visvabharti ( $1^{\text {st }}$ edn.).

4. Shri Girija Dayal Shukla (1969) Bhela, Bhela Samhita by Chaumkhambha Vidya Bhavan( $\left(1^{\text {st }}\right.$ edn.).

5. Pandit Shri Ram Sharma Acharya (1969) Brahma Vidya khand 108 Upanishada by Sanskriti Sansthan, Barielly ( $4^{\text {th }}$ edn.).

6. P V Sharma, Chaukhambha (1981) Charaka, Charaka Samhita Crientalia( $1^{\text {st }}$ edn) Varanasi, India.

7. R.K.Sharma and Bhagwan dash (2001) Charaka, Charaka Samhita, Chaukhambha Crientalia( $5^{\text {th }}$ edn) Varanasi, India.

8. Charaka, Charaka Samhita with Ayurveda Dipika (2016) commentary by Chakrapanidatta edited by Vaidya Yadavaji Trikaji Acharya, Chukahmba Surbharati Prakashan Varanasi, Reprint.

9. Charaka, Charaka Samhita with Charak Chandrika Hindi commentary by Pt. Dr. Brhamnand Tripathi foreword by Dr. Ganga Sahay Pandey part 1 , Published by Chaukhamba Surbharati Prakashan, Varanasi. 
10. Harita, Harita Samhita (1927) by Vaidya Ravidatta Shastri Hindi commentary, Khemraja Sri Krishnadas, Bombay.

11. Madhavakara, Madhava Nidanam (2005) (Rog-viniscaya) with the Sanskrit commentary Madhukosha, Vijayrakshita \& Srikanthdatta, edited by 'Vimala' 'Madhukara' Hindi commentary \& Notes by Dr. Brahmanand Tripathi, Vol $1^{\text {st }}$, Chaukhamba Subharti Prakashan, Reprint edition.

12. Maharishi Dayanand Saraswati, Yajurved-Samveda, Dayananda Sansthan, New Delhi 5

13. Pt. Motilal Shastri, Yajurvediya Kanthopanishad-hindi Vigyana Bhashya, (1997) Rajasthan Patrika Limited, Jaipur, $1^{\text {st }}$ edn.

14. Sharangadhara, Sharangadhara samhita (2006) with the commentary Aadhamalla's dipikas And kasirama's gudhartha-dipika edited by Pt. Parashuramshatri Vidyasagar, introduction by Prof. C.B. Jha, 1st edition, published by Chaukhamba Surbharati Prakashan, Varanasi.

15. Sharngadhar, Shararngadhara Samhita, (2009) edited with A treatise on Ayurveda Eng.Commentary by Prof. K.R.Srikantha Murthy, Chaukhambha Orientalia Varanasi, Edition.

16. Sri Ram Acharya, Ved Murti Taponishtha Pandit (2005) Atharvaveda Samhita, Bhag $1^{\text {st }}$,YugNirmanaYojana, Gayatri Tapobhumi, Mathura (U.P), Reprint edition.

17. Sushruta, Sushruta Samhita (2008) of Maharshi Sushruta, Kaviraja Ambikadutta Shashtri, edited with Ayurveda-Tattva-Sandipika foreword by Dr. Pranajivana Manekchanda Mehta Chaukhambha Sanskrit Sansthan reprint edition.

18. (2000) Sushruta, Sushruta Samhita originally expounded by Kashiraja Divodasa Dhanvantri with the commentary Sushrutartha Sandipana Bhasya, Harana Chandra Cakravarti, Vol 2, Prologue in Sanskrit \& English, Prof. Jyotir Mitra Chaukhambha Subharati Prakashan, Reprint edition.

19. Vagbhatta, Ashtanga Hridaya (2009) edited with 'Nirmala' hindi commentary by Dr. Brahmanand Tripathi ,Chaukhambha Sanskrit Pratisthan, Delhi, Reprint.

20. Vagbhatta, Ashtanga Hridaya (1991) Text English Translation, Appendix and Indices, Vol. I-III by K.R. Srikanthmurthy, Krishnadas Academy, Vanarasi.

21. Vagbhatta, Ashtanga Hridaya (2002) with the commentaries Sarvangasundara of Arunadatta \& Ayurvedarasayana of Hemadri annonated by Dr. Anna Moreswarkunte and krsna Ramchandra Sastri Naure, edited by Pt. hari Sadashiva Shastri Paradakara Bhisagacharya,Chaukambha surbharati Prakashan, Varanasi, reprint edition.

22. (1990) Vagbhatta, Ashtanga Sangraha, edited by Vaidya Pandit Ramcandra shastri Kinjwadekar, English Inroducion by Vaidya Bhagwan Dash ,Sri Satguru Publications, reprint edition.

23. (2005) Vagbhatta: Ashtanga Hridaya, Edited by Prof. Murthy K.R. Srikanth, Krishnadas Academy, Varanasi. 8 th edition. Pp.167.

24. (2012) Vriddha Jivaka, Kashyapa Samhita or Vrddha Jivkiya Tantra , revised by Vatsya with Sanskrit introduction by Nepal Rajaguru Pandit Hemraja Sarma with the vidyotini Hindi Commentary \& Hindi translation of Sanskrit introduction by Ayurvedalankar Srisatyapala Bhisagacharya, Chaukhambha Sanskrit Sansthan, Varanasi, reprint edition.

25. (1996) Vriddha Kashyap, Kashyap Samhita- English Translation by Prof. P.V. Tiwari Choukhamba Vishvabharti, Varanasi, $1^{\text {st }}$ Edn.

26. (1999) Desai Ranjit Rai, Ayurvediya Kriya Sharir, Shri Vaidyanath Ayurveda Bhavan Ltd.

27. (2007) Gananath Sen, Pratyaksha Shariram, Part $1^{\text {st }}$, Chowkhambha Krishnadas Academy, Varanasi, Reprint edition.

28. (2011) Prof. (Km.) Premavati Tewari, Ayurvediya Prasutitantra Evam Striroga, Chaukhambha Orientalia, Varanasi, reprint edition.

29. (2011) Arthur C. Guyton \& john E. HALL Textbook of Medical physiology $\left(12^{\text {th }}\right.$ edn) W.B Saunders.

30. Bourne and Howkins Shaw's text book of Gynaecology (2002) (12 th $^{\text {th }}$ dn) B.I Churchill livingstone Pvt.Ltd, New delhi, India.

31. B D Chourasia (1977) Human Anatomy Regional and Applied., ( $3^{\text {rd }}$ edn.), CBS Publishers and Distributers, Daryaganj, New Delhi.

32. Hiralal Konar (2006) Dr. D.C.Dutta Text Book of Obstetrics., New Central Book agency Kolkata, India.

33. Peter L Williams (1995) Gray, Gray's anatomy, the anatomical basis of medicine and surgery., (38 ${ }^{\text {th }}$ edn.), Churchill Livingstone Robert Stevenson House ,Edinburgh, Scotland, UK

34. Anne M R Agur, Arthur F Dalley (2013) J.C.B.Grant, Grant's Atlas of Anatomy (13 ${ }^{\text {th }}$ edn.), Wolters Kluwer Pvt Ltd, New Delhi, India.

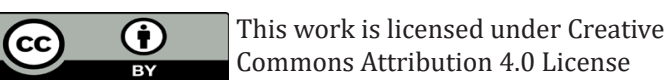

DOI: $10.32474 /$ IGWHC.2018.01.000107

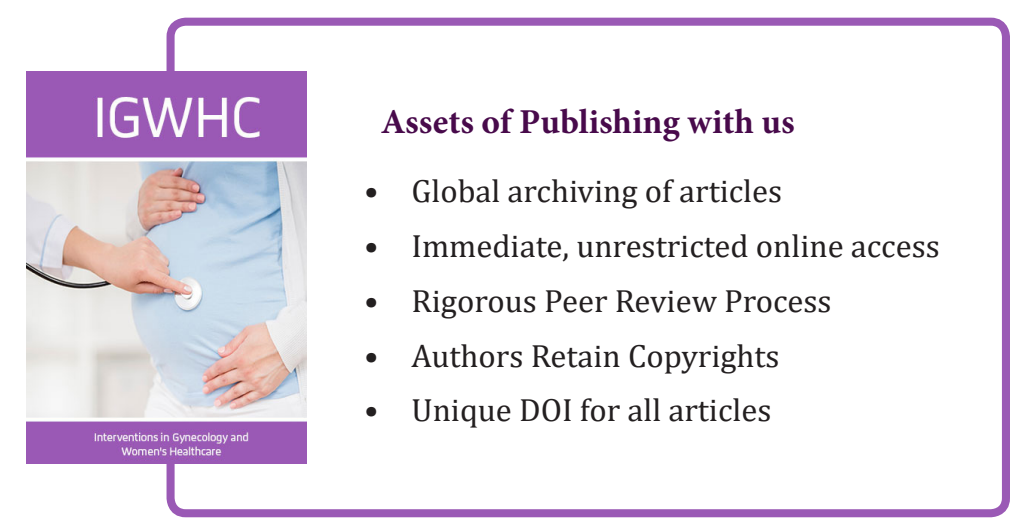

